\title{
PEDAGOGY
}

\section{Modern Approaches to Development to Foreign Language Communicative Competence of Military Lecturers}

\author{
M. S. Aristarkhova \\ National Defense University of Ukraine named after Ivan Cherniakhovskyi \\ Corresponding author. E-mail: aristarkhovamargarita@gmail.com
}

Paper received 08.07.19; Accepted for publication 21.07.19.

\begin{abstract}
https://doi.org/10.31174/SEND-PP2019-202VII82-01
\end{abstract}
\begin{abstract}
The article deals with current state of development of foreign language communicative competence of military lecturers, analyzes normative documents of foreign military and pedagogical internship. The paper presents results of questionnaire "The Expert Estimation of Development of Foreign Language Communicative Competence of Lecturers' of HMEI", which was aimed at the study of modern state of foreign language communicative competence development of lecturers of HMEI and their participation in foreign pedagogical internship.
\end{abstract}

Keywords: foreign language communicative competence, higher military educational institutions, military lecturers, communication.

Introduction. The important precondition for efficient integration of higher education according to the NATO standards to the Alliance's international system of higher education is foreign language communicative competence of lecturers of higher military educational institutions (HMEI). Higher military school should accomplish new tasks concerning foreign military training of military professionals. One of such tasks is to direct educational process to results of interactive, flexible, creative professional communication. The foreign communicative competence of lecturers of HMEI is an instrument used in order to fulfill immediate tasks of higher military school development such as: implementation of leading technologies of modern types of armament production, military equipment, informational and material and technical maintenance of military operations, promotion of strategic communication in the defense sphere, creation of efficient system of military professional's training according to the current standards.

The review of publications on the topic of the article. The system of views according to the foreign training of personnel of the Armed Forces of Ukraine, main principals and regularities, standards, which defines the strategy for actions for obtaining foreign language competence at high level is outlined in the Concept on Foreign Language Training of Personnel of the Armed Forces of Ukraine. The concept determines the following aims of foreign language training of personnel:

achievement by the Armed Forces of Ukraine intercompatibility with armed forces of member-states and partners of NATO, which is a prerequisite for gaining a membership in the Alliance and assuring a capability to participate in the joint operations and multinational training under the guidance of NATO;

participation of Ukrainian unites in the international operations for peacekeeping, anti-terrorist and search and rescue operations under the aegis of NATO;

introduction to the Armed Forces of Ukraine Euro-Atlantic standards and efficient participation in activities of international cooperation;
- training of personnel for education abroad according to international programs of military education and training;

training of personnel to performing duties according to the post, which require usage of international languages [0, p.3-4].

The Concept of Foreign Language Training of Personnel of the Armed Forces of Ukraine is a part of general training system of military men and workers of the Armed Forces of Ukraine and it is a constituent part of general training system of military men and workers of the Armed Forces of Ukraine, complex of affirmed, planned and consequential actions of educational and training character aimed at formation ability and readiness of personnel to provide communication, which requires usage of foreign language while performing professional activities[0]. Moreover, this document explains the definition of special foreign language training as study of foreign language by personnel, aimed at acquirement of necessary amount of specialized professional language material.Thus, the Concept of Foreign Language Training of Personnel of the Armed Forces of Ukraine considers the foreign language training in general and doesn't separate lecturers as the category, and also it doesn't consider foreign military and pedagogical internship as a productive form of advanced vocational training and professional improvement of military lecturer.

The foreign communicative competence of lecturers of HMEI is an instrumental competence, which provides improvement of military pedagogue's professionalism aided by foreign language, his/herself-education and a factor of European integration, introduction of NATO standards and implementation of advanced experience to educational process.

The development of foreign language communicative competence in the system of post-graduate education (formal - courses of advanced training, military and pedagogical internship, distance learning; non-formal self-development; informal - communication, life experience) and with help of great amount of different methods, forms and means. We consider, that arrangement of academic connection between military 
educational institutions, generalization of best practices of pedagogical experience of leading military institutions of NATO, participation in the joint educational and scientific projects, development of integrated educational programs, activization of academic mobility, arrangement of foreign pedagogical internship of lecturers of HMEI will provide conditions for positive solution of this scientific problem.

The foreign language communicative competence is an instrument, which provides for lecturers an access to foreign pedagogical internship, and its development should be directed at improvement of professional competences, acquirement of best practices of military professionals according to NATO standards.

In accordance with "Plan of Staff Assistance of International Programs of Servicemen and Workers of the Armed Forces of Ukraine Training in Military Educational Institutions of Foreign States in 2019",the academic mobility of servicemen is provided for professional training in the HMEI of member-states of the NATO, and also in order to adopt best practices and standards of Alliance and its further implementation. International agreements of Ukraine with countrymembers of the North Atlantic Treaty Organization provides advanced training of lecturers abroad only for lecturers of English language (Defense Language Institute English Language Center, the USA, School of English Language Training of the Armed Forces of Canada, Federal Institution of Foreign Language).

Foreign military and pedagogical internship allows not only to improve level of foreign language training of Ukrainian lecturers of HMEI, but also to strength academic connections between military educational institutions, to study and to spread best practices of leading military institutions of NATO, to participate in educational and scientific projects, to develop intergrated educational programs, to expand academic mobility and all these will produce concurrent circumstances.

The problem of foreign language training of professionals of national security and defense sphere are discussed in the theses of T. Vakolyuk [0], O. Volobueva [0], O. Zastelo [0], O. Yefimova [0], V. Krykun [0], O. Lagodynskyi [0].

A lot of academic papers are devoted to the issue of foreign language competence of cadets and future masters of military management formation. Author of thesis O. Yefimova studies problem, of formation of foreign language communicative competence of cadets in the course of professional training at the HMEI, and defines foreign language communicative competence as knowledge of language, high level of practical usage of verbal and nonverbal means, and also experience of language use on altenative and adaptive level depending on specific verbal situation. [0, p. 97].

V. Krykun deals with issue of formation of foreign language professional competence of future masters of military administration with help of technology of blended learning. Consequently, the foreign language professional competence of the future military management masters is considered as an integrative professional entity, which is a set of language knowledge, foreign language skills and knowledge, experience in their use in a foreign language environment, and includes professionally important qualities of the officer, reflecting the ability to function in the foreign environment and readiness to fulfill the tasks during joint combat operations with NATO units. [0, p. 45].

In addition to analyzed theses, the problem, of foreign language training and development of foreign language communicative competence of professionals in the sphere of national security and defense investigate: modeling of professional situations in the course of educational process in order to develop foreign language communicative competence of cadets of HMEI (O. Bernatska) [0]; formation of foreign language competence of future border officers due to enriching the content of the educational material with creative tasks (I. Bets) [0, 0]; psychological grounds of development of skills of future military professional and peculiarities of professional foreign language communication of border officers (O. Volobueva) [0]; introduction of bilingual education as an effective method of development of foreign language competence in the HMEI (T. Vakolyuk) [0].

O. Lahodynsky focuses on the development of English language competence using productive forms of speech activity of future professionals of the military-diplomatic service, examines the strategies of teaching English language to the future masters of military management in international relations taking into accoun their individual psychological peculiarities and defines foreign language communicative competence as integral, intellectual, professional and personal formation, which determines the ability and readiness of the individual to perform oral and written communication in all types of speech activity. [0, p. 303].

The purpose of the article is to unveil modern approaches to development of foreign language communicative competence of lecturers of HMEI in the post-graduate system.

Research methods: systematic approach, analysis of professional literature and theses related to the topic of study, normative documents, interpretation of questionnaire results, synthesis of further recommendations.

The results and discussion. Modern scholars pay attention to formation of foreign language communicative and professional competence in the course of future officers and masters of military management professional training, sustained psychological and pedagogical condition and its formation, and also were revealed its content, structure. The problem of the development of foreign communicative competence of lecturers of HMEI in the framework of formal and informal education

It is also relevant the study of pedagogical modeling of foreign language competence development of lecturers, while there is no strict mechanism of military lecturer self-development as a professional, and there is also no understanding of peculiarities and essence of foreign language communicative competence.

In order to define attitude and also place and role of foreign language communicative competence of lecturers of HMEI in the system of lifelong learning, the questionnaire of military lecturers was held in National Defence University named after Ivan Cherniakhovskyi (Kyiv), Hetman Petro Sahaidachnyi National Army Academy (Lviv), Zhytomyr Military Institute named after 
Serhyi Korol'ov, Ivan Kozhedub National Air Force University (Kharkiv). Questionnaires were created for experts (scientific and pedagogical workers).

The group of experts consists of 25 scientific and pedagogical workers, who have degree of Doctor of Sciences (Phd), academic rank of professor, associate professor, senior research assistant, work experience in the sphere of higher military school more than 5 years, and also completed test in order to define language level (English).

According to the created questionnaire "The Expert Estimation of Development of Foreign Language Communicative Competence of Lecturers' of HMEI" was held the study of modern state of foreign language communicative competence development of lecturers of HMEI and their participation in foreign pedagogical internship. The questionnaire gave us an opportunity to find out the main tasks of foreign language communicative competence of lecturers of HMEI according to the respondents, their readiness to successive and efficient foreign language communication of professional direction, their skills to orientate in certain situations of foreign language communication and to provide development of professional competence, to increase the level constantly, to develop their professional competence, to adopt best practices of leading memberstates of NATO and to implement it to the educational and professional training of students, to produce a need of self-education throughout life.

The questionnaire of experts allows to define the problem of development of foreign language competence of lecturers of HMEI. So, the following results were provided about determination of lecturers' foreign language knowledge level (Img. 1.3.1): HMEI

Img. 1. Foreign Language Knowledge Level of Lecturers of

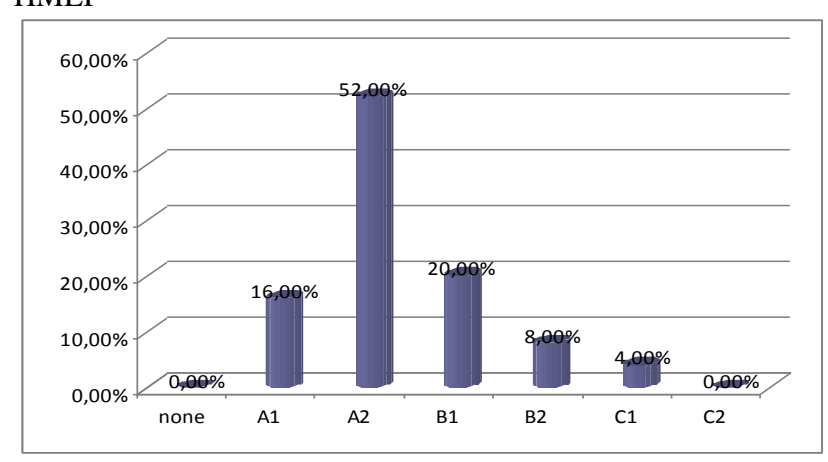

A1 (Elementary) - knowledge of alphabet and minimal vocabulary, understanding of simple words and common phrases;

A2 (Pre-Intermediate) - knowledge of common words and phrases, ability to communicate in simple and ordinary situations;

B1(Intermediate) - knowledge of grammar basics and good vocabulary, ability to solve majority of problems with the help of foreign language or while communication with representatives of other countries, to speak about simple topics;

B2 (Upper-Intermediate) - knowledge of grammar and enough vocabulary, ability to speak fluently with native speakers on various subjects;
C1 (Advanced) - to be fluent in foreign language either in ordinary life, or in study and work, knowledge of grammar and ability to speak fluent without any hesitations on different topics.

It should be noted, that the examined lecturers answered to the question about their satisfaction with knowledge level of foreign language. We received the following results: $9 \%$ are satisfied with their knowledge level, $36 \%$ are partially satisfied, $36 \%$ are requiring of improvement and $20 \%$ are not satisfied at all. However, $16 \%$ are constantly working on improvement of their foreign language competence and $68 \%$ are sometimes working on improvement. Also, 52\% of examined lecturers considers that knowledge of foreign language helps to career progress, and only $24 \%$ constantly use foreign language in the course of their scientific work and while preparing for the classes. It should be pointed out, that only $8 \%$ participated in foreign military and pedagogical internship.

Also $20 \%$ of examined lecturers constantly monitor the literature of foreign scholars, which relate to their scientific interests.

The following data were received about the most efficient forms of development of foreign language competence:

Img. 2. The Forms of Development of Foreign Language Competence of Lecturers of HMEI

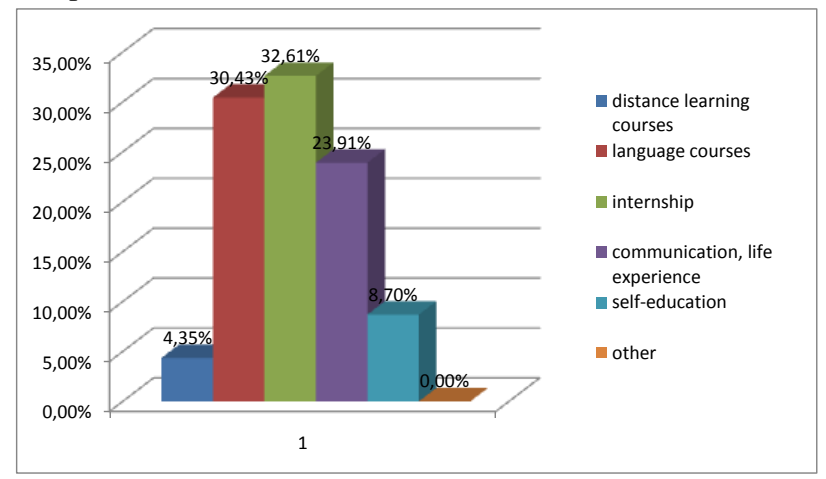

The majority of examined lecturers stated about the most efficient tools of foreign language competence improvement: books and printed texts( $48 \%)$; pictures, diagrams, maps (4\%); audiovisual (television, films) (48\%); audio (20\%); software, computers (44\%) (according to the questionnaire, several answers were allowed).

Conclusions. The majority of examined lecturers state, that language immersion, professional communication with the help of foreign language and also foreign military and pedagogical internship will help to develop foreign language communicative competence of lecturers of HMEI. It is also noted, that there are no classes for military lecturers in order to improve foreign language training and also to expand academic relationships between military educational institutions, study and wide spreading of the best practices of leading military schools of NATO, participation in joint educational and scientific projects, development of academic mobility of lecturers.

The experts consider, that foreign military and pedagogical internship will help to develop foreign language communicative competence, and also to introduce NATO standards into all spheres of military 
activity and achievement of the criteria, which are necessary for gaining a membership in NATO.

The abovementioned show the presence of gaps in the organization of educational process with the help of modern technologies of study for development of foreign language communicative competence of lecturers of HMEI. The developed foreign language communicative competence will provide possibilities of academic mobility, increasing of professional competence and readiness to solve educational and professional tasks successfully. There are a few works of scholars, that highlights this subject in methodological literature, which

\section{REFERENCES}

1. The Order of Ministry of Defense of Ukraine from 01.06.2009 № 267 « The Concept on Foreign Language Training of Personnel of the Armed Forces of Ukraine and the Plan of Realization of the Concept on Foreign Language Training of Personnel of the Armed Forces of Ukraine ».

2. Plan of Staff Assistance of International Programs of Servicemen and Workers of the Armed Forces of Ukraine Training in Military Educational Institutions of Foreign States in 2019 , URL:http://www.mil.gov.ua/content/tenders/Plan_KZ2019.p df (Date of Access: 14.06.2019).

3. Bernatska O. V. Modelling of the Professional Activity Situations in Training of Cadets to Foreign Language: manual. 2001. № 18. P. 70-75.

4. Bets I. O. Enriching the Content of Educational Material with Creative Tasks during of Foreign Language Training Formation of Future Border Guards. Bulletin of National Academy of the State Board Guard Service of Ukraine. Pedagogy. 2018. Iss. 2. URL: http://nbuv.gov.ua/UJRN/Vnadped_2018_2_6 (Date of Access: 14.06.2019).

5. Bets I. O. Methods of Activization of Educational and Cognitive Activity of Future Border Guards in the Process of Learning a Foreign Language. Bulletin of National Academy of the State Board Guard Service of Ukraine. Pedagogy. $2017 . \quad$ Iss. $2 . \quad$ URL: http://nbuv.gov.ua/UJRN/Vnadped_2017_2_6 (Date of Access: 14.06.2019).

6. Vakolyuk T. V. Pedagogical Conditions of the BorderguardCadets` Foreign Language Intensive Studying: thesis for degree Candidate of Sciences in Pedagogy: 13.00.04 / National Academy of the State Board Guard Service of are used in the system of professional and advanced training of lecturers of HMEI.

The main attentions of scholars is paid to formation of foreign language communicative competence in higher school. This problem requires special attitude as it is one of the priority tasks due to expansion of military and educational cooperation, increasing professional level of lecturers. The latter states about necessity of updating educational and methodological literature for higher military school, including to manuals, books relevant materials, which will provide development of foreign language communicative competence of lecturers of HMEI.

Ukraine named after Bohdan Khmelnytskyi. Khmelnytskyi, 2003. 199 p.

7. Volobuyeva O. F. Psychological Bases of Foreign Language Abilities Development of Future Military Professional: thesis for degree Doctor of Sciences in Psychology:19.00.07 National Academy of the State Board Guard Service of Ukraine named after Bohdan Khmelnytskyi. Khmelnytskyi, 2010. 465 p.

8. ZasteloO. V. Development of Diagnostic Competence of Foreign Language Teachers of the Higher Military Establishments in Postgraduate System: thesis for degree Candidate of Sciences in Pedagogy 13.00.04 / National Defense University of Ukraine named after Ivan Cherniakhovskyi. Kyiv, 2018. 375 p.

9. Yefimova O. M. Formation of Foreign Language Communicative Competence of Cadets in the Course of Professional Training at the HMEI. Herald of the National Technical University of Ukraine «Kyiv Polytechnic Institute».2013.Iss. 1. P. 95-105.

10. Kostenko N. I. Peculiarities of Foreign Language Communicative Competence Formations of Students of Nonphilological.

http://www.nbuv.gov.ua/portal/soc_gum/Znpkhist/ 2012_5/12knizns.pdf (Date of Access: 14.06.2019).

11. Krykun V. D. Formation of Foreign Language Professional Competence of Future Military Management Masters: thesis for degree Candidate of Sciences in Pedagogy: 13.00.04 / National Defense University of Ukraine named after Ivan Cherniakhovskyi. Kyiv, 2018. 244 p.

12. Lahodynsky O. S. Linguistic Problems of the would-be Masters' of Command and Control in International Relations English Language Training. Theoretical Issues of Culture, Education and Upbringing. 2012. № 45. P. 101-105. 